\title{
EFL Students' Awareness and Use of Vocabulary Learning Strategies in EFL Classes: The Case of Grade 11 Students at Woreta Secondary and Preparatory School, South Gondar, Ethiopia
}

\author{
Asafew Kelebu Abtew \\ Lecturer at Mekdela Amba University, College of Social Science and Humanities, Department of English \\ Language and Literature, Ethiopia
}

\begin{abstract}
The purpose of this study was to study grade 11 students' awareness and use of vocabulary learning strategies in EFL classes at Woreta Secondary and Preparatory School. To conduct this study, mixed research (qualitative and qualitative) method was employed due to the nature of the research problem. The population of the study were Grade 11 students who were enrolled in the year 2009 E.c and five Grade 11 EFL teachers. As it was impossible to incorporate all students in this study, 120 (14\%) out of the total population of 841 students were selected using simple random sampling method. Hence, 120 students were all selected for questionnaire. Furthermore, six students were randomly selected from those 120 students and 2 EFL teachers who were teaching English were selected for interview. Data were collected using questionnaire, interviews and observations. The data obtained from the samples were analyzed qualitatively and quantitatively. The quantitative data were presented using frequency and percentage. The findings of this study indicated that the students did not know many vocabulary learning strategies and did not think that these vocabulary learning strategies are important to increase their word power. The students employed only a few vocabulary learning strategies. Finally, it was concluded that the students lack awareness about the vocabulary learning strategies and they did not use as many vocabulary learning strategies as they can. Based on the find of the study the researcher recommended that teachers must create awareness about vocabulary learning strategies and should give opportunities for their students to practice different vocabulary learning strategies.
\end{abstract}

Key terms: vocabulary learning strategies, memory strategies, cognitive strategies, social strategies, awareness DOI: $10.7176 /$ JLLL/76-02

Publication date: February $28^{\text {th }} 2021$

\section{INTRODUCTION}

Vocabularies are important to express one's own feeling effectively. It is a core component of language proficiency and provides much of the basis for how well the learners listen, speak, read and write. To develop the students' vocabulary knowledge, vocabulary learning strategies are used. Concerning to this, Cameron (2001:92) states vocabulary learning strategies as "Actions that learners take to help themselves understand and remember vocabulary." According to Hatch and Brown (1995), the vocabulary learning strategies that students use has greater impact on the success of their vocabulary learning. One way of tackling a large number of unknown words is through vocabulary learning strategies. Vocabulary learning is considered by many students as an important and challenging factor in learning a foreign language. Therefore, it is crucial to find effective ways of learning vocabulary to reduce the challenges that students face and to give opportunities for the students to actually use the words.

Students need to acquire vocabulary learning strategies in order to discover the meanings of new words. The strategies should be useful within the classroom as well as when students are in a situation where they encounter new and unfamiliar words on their own. The vocabulary learning strategies should also help students acquire new vocabulary words that they hear, read and see. Having different learning opportunities will help students to increase overall language ability by improving their vocabulary.

Vocabulary should be integrated into learning the four skills-listening, speaking, reading and writing. Therefore, to listen to someone's speech very well, to talk with different people, to read any written composition and to write any piece of literary text, the knowledge of vocabulary plays a vital role. The knowledge of vocabulary also plays a useful role in order to communicate through any form of language. It is also used to make invitations, to express feelings and so on. Vocabulary is such important language knowledge that the English language students have to develop for any type of written or spoken communicative purposes. Particularly in English for academic purposes setting, it becomes necessity to elementary, intermediate and advanced level students to understand lectures, discussions, seminars, panel discussions, conferences and other academic spoken discourses and to take notes from them.

In Ethiopia, although English is the medium of instruction starting from grade 7 up to well-advanced levels, no particular attention has been paid to help students develop their vocabulary learning strategies which truly 
enable them to perform well in their learning process in to practice. It implies that learners use limited range of vocabulary learning strategies inappropriately. Regarding to this, some local studies have been conducted in relation to the vocabulary learning strategies. Among them, Ahmed (1998) indicates that the 'good learners' differed greatly from the 'low achiever' ones in strategies use. His major finding indicates that the former ('high achiever' learners) not only use more strategies but also differ from poor learners in that they learn words in context and use a dictionary as a resource. Learners, however, show no interest in learning words in context and are generally less aware of what they could learn about new words. The other study is conducted by Abebe G/Tsadik (1997) on strategies of vocabulary learning employed by first year students at A.A.U. His finding indicates that a wide range of English vocabulary acquisition strategies were reported by the target sample students but only a few of the strategies were reported to be used by a large number of the students.

However, up to this time, none of these studies were actually intended to conduct the study on grade 11 students' awareness and use of vocabulary learning strategies in EFL classes in Ethiopian context. Therefore, having this in mind, the researcher is inspired to conduct a research on this research area at Woreta Secondary and Preparatory School.

The main objective of this study is to investigate the grade 11 students' awareness and use of vocabulary learning strategies in EFL classes for learning new words. Based on the general objective, the following specific objectives were set.

1. To explore the students' awareness of vocabulary learning strategies for learning new words.

2. To explain the practice of vocabulary learning strategies in their vocabulary learning in EFL classes.

\section{RESEARCH METHODOLOGY}

\subsection{Design of Research}

The research framework used in this study was mixed research design which made use of both quantitative and qualitative methods. This method was found to be appropriate for this study which aimed at students' awareness and use of the vocabulary learning strategies. This was because it provides better understanding of the research problem and answers the research questions than any other approach (Cresswel 2014). In relation to this, Ary et al (2010: 567) states that mixed methods research can take advantage of the combined strengths of qualitative and quantitative approaches and can use the strengths of one method to overcome the weaknesses of another.

\subsection{Samples and Sampling Technique}

The participants of the study were Grade 11 students who were enrolled in 2009 E.C. and five grade 11 EFL teachers. As it was impossible to incorporate all students in this study, $14 \%$ of sample students out of the total population of 841 students, were selected using simple random sampling to participate in the study. According to Kumar (2006: 94) it is sometimes suggested that one should select 10-20\% of the accessible population for the sample.

After selecting the sample population of the study for questionnaire, the participants for interview were selected. Six students were randomly selected from those 120 students and the 2 English teachers who taught students English were selected for interview.

\subsection{Data Collection Instruments}

To elicit the necessary data from the subjects, questionnaires, interview and observation were used. Multiple data gathering instruments that are consistent with the purpose of the study are advisable ( $\mathrm{O}^{\prime}$ Malley and Chamot, 1990).

\subsubsection{Questionnaire}

This questionnaire was administered to 120 grade 11 students to elicit about the students' awareness and use of vocabulary learning strategies in EFL classes. The questionnaire contained 20 closed - ended items. The students' questionnaire was translated into Amharic so that students could understand and respond to the items easily. The items were adopted from Schmitt (1997) in line with the objectives of the study and the review literature.

\subsubsection{Interviews}

Semi-structured interviews were used to gather data for cross-checking. Semi-structured interviews were preferred for the sake of making the questions flexible and enabled the two groups of subjects to express their feelings or emotions. The researcher believed that they would help him to get information that might not be obtained through the other data gathering tools.

The interviews were conducted with six students and two English. These six students were selected using every twentieth interval from the total population of the 120 sample students and two EFL teachers who were selected from the total population of five EFL teachers who had been teaching those sample students. The interviews contained the vocabulary learning strategies. 


\subsubsection{Observation}

The researcher observed two English Language teachers in the teaching-learning process and students' practice in the two EFL classrooms. The observation was carried out using observation checklist. Using the checklist, the two sections were observed two times each. Thus, a total of four classroom observation was taken place. The observation items were constructed to be responded on the three points rating scales such as 3 stands for Unsatisfactory, 2 stands for Satisfactory and 1 stands for Excellent.

The major purpose of observation was to triangulate the information collected through interview and questionnaire and to investigate the extent of reliability and dependability of the students' expected responses. The observation was meant to examine the vocabulary learning, the strategies students' reaction towards the vocabulary teaching techniques and the role of classroom teachers. After the observation, analysis and discussion were immediately arranged concerning the observation.

\subsection{Procedure of Data Collection}

In order to conduct this study, the following data collection procedures were employed. First, the questionnaire had been conducted with 120 students before the interview. The questionnaire was coded according to the participating subjects. After the data were carefully gathered using the close ended questionnaire, the data were quantitatively analyzed and discussed by using numbers and percentages. Second, the six students and the two EFL teachers were briefly oriented before interviewing them. At the end, after the data were carefully gathered using the semi-structured interviews, the data were qualitatively analysed and discussed by using descriptions.

\subsection{Methods of Data Analysis}

The data obtained from the two subjects through questionnaire, interview and observation were analyzed using both quantitative and qualitative methods. The data collected by the questionnaire was analyzed quantitatively by using frequency and percentage, whereas, the data collected using interview and observation were analyzed qualitatively. This mixed method was made in the interpretations, analyses and discussions.

Statements directly related students' awareness and use of the vocabulary learning strategies ) were coded as: 'strongly agree' $(\mathrm{SA})=1$, 'Agree' $(\mathrm{A})=2$, 'Undecided' $(\mathrm{U})=3$, 'Disagree' $=4$ and 'Strongly disagree' $=5$. In the same way, the items of the questionnaire for classroom practice were coded as: 'Always' (A) = 1, 'Often' $(\mathrm{O})=2$, 'Sometimes' $(\mathrm{ST})=3$, 'Rarely' $(\mathrm{R})=4$ and 'Never' $(\mathrm{N})=5$. Moreover, the items of the classroom observation checklist were coded as: 'Excellent' $(E x)=3$, 'Satisfactory' (Sat) $=2$ and 'Unsatisfactory' $($ Un $)=1$. The frequency and percentage of each item were calculated. Therefore, the analysis of the questionnaires and classroom observations were carried out by comparing the calculated percentage and frequencies. The qualitative method, on the other hand, was employed for the analysis of the data collected through observation, the students' and teachers' interviews.

\section{Data Analysis and Discussion}

\subsection{Analyses and Discussions of Questionnaire}

In this section, the questionnaire was about vocabulary learning strategies. In this questionnaire, the researcher listed the four most known vocabulary learning strategies thematically. Every known vocabulary learning strategy contains some specific vocabulary learning strategies. The questionnaire consisted of twenty items to the 120 sample students (participants). These participants ticked out the method they used. The data gathered from questionnaire were analyzed and discussed in numbers and percentages in the following way.

\section{Table 1. Learning New Words Using Memory Strategies}

\begin{tabular}{|c|c|c|c|c|c|c|c|c|c|c|c|c|c|}
\hline S. & \multirow[b]{2}{*}{ Questions } & \multicolumn{2}{|l|}{$\mathrm{A}$} & \multicolumn{2}{|l|}{$\mathrm{O}$} & \multicolumn{2}{|l|}{ St } & \multicolumn{2}{|l|}{$\mathrm{R}$} & \multicolumn{2}{|l|}{$\mathrm{N}$} & \multicolumn{2}{|c|}{ Total } \\
\hline $\mathrm{N}$ & & II & 0 & II & 0 & II & or & II & or & II & 0 & II & 0 \\
\hline 1 & $\begin{array}{l}\text { How often do you learn the meanings } \\
\text { of new words using synonyms? }\end{array}$ & 1 & ' & ' & ' & $\bar{m}$ & $\begin{array}{l}\infty \\
\ddot{v}\end{array}$ & ชิ & $\frac{n}{n}$ & $\stackrel{\sim}{\text { v }}$ & 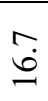 & 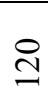 & 8 \\
\hline 2 & $\begin{array}{l}\text { How often do you learn the meanings } \\
\text { of new words using antonyms? }\end{array}$ & $=$ & $\vec{a}$ & 1 & 1 & లి & กี & オ & $\begin{array}{l}\dot{\nabla} \\
\dot{n}\end{array}$ & $n$ & $\stackrel{n}{\simeq}$ & తి & 8 \\
\hline 3 & $\begin{array}{l}\text { How often do you guess the meanings } \\
\text { of new words in a text using various } \\
\text { contextual clues? }\end{array}$ & ' & ' & ' & ' & 0 & $\stackrel{m}{\eta}$ & $\underset{0}{ \pm}$ & ఠ் & ' & ' & 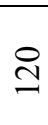 & 8 \\
\hline 4 & $\begin{array}{l}\text { How often do you use sufficient } \\
\text { vocabulary when you communicate } \\
\text { with others effectively? }\end{array}$ & ' & ' & I & ' & 이 & $\underset{0}{0}$ & ㅇ & $\stackrel{n}{\sim}$ & $\stackrel{R}{\circ}$ & $\begin{array}{l}\forall \\
\infty \\
\infty\end{array}$ & ิㅡ & 8 \\
\hline
\end{tabular}

Key: $\mathrm{F}=$ Frequency, $\mathrm{A}=$ Always, $\mathrm{O}=$ Often, $\mathrm{St}=$ Sometimes, $\mathrm{R}=$ Rarely, and $\mathrm{N}=$ Never Table 1 presents the students' response to the frequency of using memory strategy for learning new words. 
It is revealed that $57.5 \%$ of the students responded rarely, $25.8 \%$ of the students responded sometimes, and the remaining $16.7 \%$ of the students responded never to item number one. They rarely learn the meanings of new words using synonyms. For item two, $53 \%$ of the students responded rarely, $25 \%$ of the students responded sometimes, $12.5 \%$ of the students responded never and the remaining $9.1 \%$ students responded always. This shows that the majority of the students $(53 \%)$ rarely learn the newly learned words using antonyms. Item three shows the students' response to the frequency of guessing the meanings of new words in a text using various contextual clues. For this item, $86.7 \%$ of the students responded rarely and the remaining $13.3 \%$ of the students responded sometimes to the statement. It is possible to say that the learning strategies, using contextual clues, are not used by the students to guess the meanings of unknown words in a text. In relation to the frequency of using sufficient vocabulary when students communicate with others effectively, $58.4 \%, 25 \%, 16.6 \%$ of the students responded never, rarely, and sometimes respectively in item 4.

Therefore, as shown in Table 1, it is possible to say that the majority of the respondents (58.4\%) had negative performance. This implies that there is a negative atmosphere in the teaching and learning process. The finding confirms with Wilkins (1982) and Krashen's (1998) report. Krashen (1998) asserts vocabulary is basic to communication. If acquirers do not recognize the meanings of the key words used by those who address them, they will be unable to participate in the conversation. And if they wish to express some ideas or ask for information, they must be able to produce lexical items to convey their meaning. Similarly, Wilkins (1982:134) has indicated that very little can be conveyed without grammar but nothing can be conveyed without vocabulary. Table 2. Learning New Words Using Cognitive Strategies

\begin{tabular}{|c|c|c|c|c|c|c|c|c|c|c|c|c|c|}
\hline \multirow{2}{*}{$\begin{array}{l}\mathbf{S} . \\
\mathbf{N}\end{array}$} & \multirow[b]{2}{*}{ Questions } & \multicolumn{2}{|l|}{ A } & \multicolumn{2}{|l|}{$\mathrm{O}$} & \multicolumn{2}{|l|}{$\mathrm{St}$} & \multicolumn{2}{|l|}{$\mathrm{R}$} & \multicolumn{2}{|l|}{$\mathrm{N}$} & \multicolumn{2}{|c|}{ Total } \\
\hline & & II & of & L & of & I & of & I & 8 & II & 0 & & 8 \\
\hline & $\begin{array}{l}\text { How often do you use translation when } \\
\text { you get a new word in a passage? }\end{array}$ & ণ & $\tilde{\sigma}$ & \& & $\stackrel{n}{r}$ & 으 & $\ddot{\infty}$ & ' & I & 1 & & 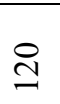 & \& \\
\hline 6 & $\begin{array}{l}\text { How often do you use vocabulary for } \\
\text { the manipulation of four main skills: } \\
\text { speaking, writing, listening and } \\
\text { reading? }\end{array}$ & ' & & ' & ' & q & 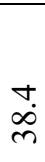 & 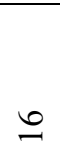 & $\stackrel{\sim}{\ddot{n}}$ & $\stackrel{\infty}{n}$ & 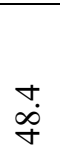 & Iิ & 8 \\
\hline 7 & $\begin{array}{l}\text { How often do you use a dictionary to } \\
\text { find out the meanings of new words? }\end{array}$ & $\simeq$ & 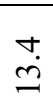 & in & $q$ & $\stackrel{N}{2}$ & $\begin{array}{l}0 \\
\stackrel{0}{0}\end{array}$ & m & $\approx$ & & & Iิ & 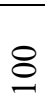 \\
\hline 8 & $\begin{array}{l}\text { How often do you use contextual clues } \\
\text { to guess the meanings of new words? }\end{array}$ & ' & & $m$ & $\tilde{\sim}$ & m & ๙ิ & $\infty$ & $\tilde{8}$ & r & $\begin{array}{l}\infty \\
\text { in }\end{array}$ & 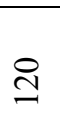 & 8 \\
\hline
\end{tabular}

Key: Always $=1$, Often $=2$, Sometimes $=3$, Rarely $=4$ and Never $=5$

Table 2 presents the students' response on using cognitive strategies to learn new words. In item $5,75 \%$ of the students responded often, $16.7 \%$ of the students responded always, and the remaining $8.5 \%$ of the students responded sometimes for using translation when they get a new word. The students' response to the frequency of using vocabulary for the manipulation of four main skills: speaking, writing, listening and reading to communicate with someone or others effectively was $48.4 \%, 38.4 \%, 13.2 \%$, of the students responded never, sometimes, and rarely respectively. To the contrary of this, McCarthy (1990) has pointed out that learning a second language involves the manipulation of four main skills; speaking, writing, listening and reading, which lead to effective communication. As it is shown in the table, $45 \%, 25 \%, 16.6 \%, 13.4 \%$ of the students responded often, rarely, sometimes and always respectively to item 7 . Therefore, from these responses, it is possible to conclude that the majority of the respondents ( $45 \%)$ indicate negative performance. Most of them often learn the meanings of new words using dictionary. The finding confirms Nation (1990), and Anderson's (1999) report. They stated that students timidly referring to a bilingual dictionary for every word that they do not understand. They also indicated that students might give up trying to understand the meaning of the text if sentences or an entire paragraph contain a small number of unknown words. In item 8, 66.7 \%, $25 \%, 5.8 \%, 2.5$ of the students responded rarely, sometimes, never, and often respectively that they use contextual clues to guess the meanings of new words. This indicates that most of the students rarely learn the meanings of new words using contextual clues. To the contrary of this Lawson and Hogben (1996) have reported that the use of contextual clues would serve as a means toward vocabulary acquisition, but this strategy was used rarely and, even when used, was not found effective. They admitted that when the context helped students to generate the meaning, they might not pay much attention to the word and, therefore, have less chance to acquire it. 
Table 3. Learning New Words Using Social Strategies

\begin{tabular}{|c|c|c|c|c|c|c|c|c|c|c|c|c|c|}
\hline \multirow{2}{*}{$\begin{array}{l}\mathbf{S} . \\
\mathbf{N}\end{array}$} & \multirow[b]{2}{*}{ Questions } & \multicolumn{2}{|l|}{ A } & \multicolumn{2}{|l|}{$\mathrm{O}$} & \multicolumn{2}{|l|}{ St } & \multicolumn{2}{|l|}{$\mathrm{R}$} & \multicolumn{2}{|l|}{$\mathrm{N}$} & \multicolumn{2}{|c|}{ Total } \\
\hline & & $\omega_{1}$ & $0^{\circ}$ & $\omega_{1}$ & $0^{\circ}$ & I & $\partial^{\circ}$ & $L_{1}$ & $d^{\circ}$ & 工 & $d^{\circ}$ & $L_{1}$ & $d^{\circ}$ \\
\hline 9 & $\begin{array}{l}\text { How often do you practice newly } \\
\text { learned words by speaking to a friend } \\
\text { and so on? }\end{array}$ & $\mid$ & $\mid$ & $\infty$ & $\hat{\sigma}$ & q & $\stackrel{m}{m}$ & 8 & 으 & $\simeq$ & $\stackrel{0}{ }$ & 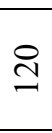 & 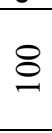 \\
\hline 10 & $\begin{array}{l}\text { How often do you ask for help when } \\
\text { you face a new word in the reading } \\
\text { text? }\end{array}$ & $\stackrel{\infty}{m}$ & $\vec{m}$ & 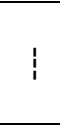 & 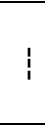 & $\underline{2}$ & $\begin{array}{l}\infty \\
\stackrel{0}{\varrho}\end{array}$ & n & $\stackrel{\sim}{*}$ & t & $\stackrel{m}{n}$ & 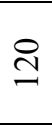 & 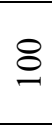 \\
\hline 11 & $\begin{array}{l}\text { How often do you ask for help to } \\
\text { present new words in language games? }\end{array}$ & 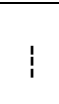 & $!$ & 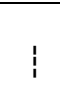 & 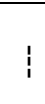 & $\underset{\sim}{ }$ & $\hat{\bar{v}}$ & 8 & in & m & $\begin{array}{l}m \\
\infty \\
\infty\end{array}$ & 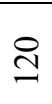 & 8 \\
\hline 12 & $\begin{array}{l}\text { How often do you ask for help to } \\
\text { pronounce and to stress new words in } \\
\text { language? }\end{array}$ & $\infty$ & $\hat{\sigma}$ & in & $\stackrel{\sim}{\sim}$ & 0 & $\stackrel{\sim}{\stackrel{\sim}{\sim}}$ & $\infty$ & $\hat{\theta}$ & $=$ & $\tilde{a}$ & $\stackrel{\text { తิ }}{ }$ & $\stackrel{\circ}{\circ}$ \\
\hline 13 & $\begin{array}{l}\text { How often do you work with others } \\
\text { when you face problems in vocabulary } \\
\text { learning strategies? }\end{array}$ & 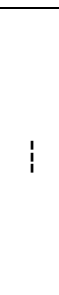 & 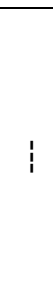 & $!$ & ! & $=$ & 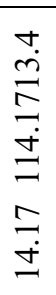 & $\infty$ & $\begin{array}{l}\hat{b} \\
\tilde{n} \\
\dot{b} \\
\infty \\
\infty \\
\hat{\delta} \\
n\end{array}$ & 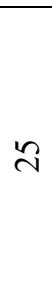 & 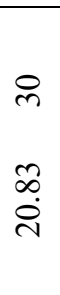 & $\begin{array}{l}\text { తి } \\
\stackrel{ }{\simeq}\end{array}$ & $\begin{array}{l}8 \\
8\end{array}$ \\
\hline 14 & $\begin{array}{l}\text { How often do you work with others to } \\
\text { use the words you learned in everyday } \\
\text { situations? }\end{array}$ & 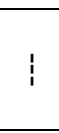 & 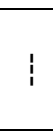 & $!$ & $!$ & ল & $\begin{array}{c}m \\
\infty \\
\infty\end{array}$ & q & $\stackrel{m}{m}$ & fo & 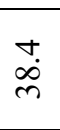 & 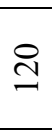 & 8 \\
\hline
\end{tabular}

Key: Always $=1$, Often $=2$, Sometimes $=3$, Rarely $=4$ and Never $=5$

In item $9,50 \%$ of the students responded rarely, $33.3 \%$ of the students responded sometimes, $10 \%$ of the students responded never and the remaining $6.7 \%$ of the students responded often to the frequency of practicing the newly learned words by speaking to a friend for learning new words.

The inability of the practice of the newly learned words by speaking to someone affects the majority of the students to develop their vocabulary knowledge. It implies that they are seen in trouble to practice and use vocabulary. The finding confirms Wallace's (1982) report. Wallace has reported that the students have been exposed to a vocabulary item of at some stage but cannot bring it to mind when they need it. In this situation, either communication breaks down altogether or else the students have no use some repair strategy such as expressing their meaning in a different way.

In relation to the frequency of asking for help when the they face new words in the reading text, $53.3 \%$ of the students responded never, $31.7 \%$ of the students responded always, $10.8 \%$ of the students responded sometimes and the remaining $4.2 \%$ of the students responded rarely.

As it is shown in table 3, $28.3 \%, 50 \%$ and $21.7 \%$ of the students responded never, rarely, and sometimes respectively to the frequency of asking for help to present new words in language games for learning new words. For item $12,66.7 \%$ of the students responded rarely, $13.2 \%$ of the students responded sometimes, $9.2 \%$ of the students responded never, $6.7 \%$ of the students responded always and the remaining $4.2 \%$ of the students responded often.

While in item 13, $56.7 \%$ of the students responded rarely, $14.17 \%$ of the students responded sometimes and the remaining 20.83 of the students responded that they work with others when they face problems in learning a new word. The Table 3 reveals that $38.4 \%, 33.3 \%$, and $28.3 \%$ of the students responded never, rarely and sometimes respectively to the frequency of working with others to use the words students learned in everyday situations for learning new words. 
Table 4. Learning New Words Using Metacognitive Strategies

\begin{tabular}{|c|c|c|c|c|c|c|c|c|c|c|c|c|c|}
\hline \multirow{2}{*}{$\begin{array}{l}\text { S. } \\
\text { N. }\end{array}$} & \multirow[b]{2}{*}{ Statements } & \multicolumn{2}{|c|}{ 1( SA) } & \multicolumn{2}{|c|}{$2(A)$} & \multicolumn{2}{|c|}{3 (Un) } & \multicolumn{2}{|c|}{4 (D) } & \multicolumn{2}{|c|}{5 (S D) } & \multicolumn{2}{|c|}{ Total } \\
\hline & & I & $\theta^{\circ}$ & 工 & $0^{\circ}$ & 工x & $a^{\circ}$ & 工s & $\partial^{\circ}$ & E & $\partial^{\circ}$ & 工 & $0^{\circ}$ \\
\hline 15 & $\begin{array}{l}\text { I give much emphasis on vocabulary } \\
\text { items than on grammar items when I } \\
\text { learn a foreign language. }\end{array}$ & 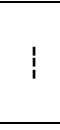 & 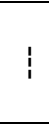 & 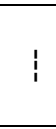 & 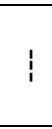 & 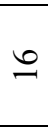 & $\stackrel{m}{m}$ & $\hat{\imath}$ & $\tilde{i}$ & $\approx$ & $\stackrel{\text { İ }}{\text { J }}$ & 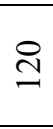 & 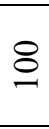 \\
\hline 16 & $\begin{array}{l}\text { I always comprehend the reading text } \\
\text { which contains some unknown words. }\end{array}$ & ণి & ఠ̊ & 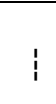 & 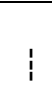 & in & 亏. & $\bar{m}$ & $\begin{array}{l}\infty \\
\stackrel{n}{\sim}\end{array}$ & 2 & $\stackrel{\infty}{n}$ & 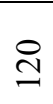 & 8 \\
\hline 17 & $\begin{array}{l}\text { I always know new words in a given } \\
\text { situation which the words are used in a } \\
\text { context appropriately. }\end{array}$ & 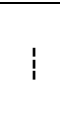 & $!$ & $!$ & $!$ & $\Xi$ & 三. & $\bar{m}$ & $\begin{array}{l}\infty \\
\ddot{v}\end{array}$ & $\stackrel{n}{2}$ & గి & 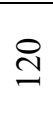 & \& \\
\hline 18 & $\begin{array}{l}\text { I use important words inside and } \\
\text { outside the classroom setting. }\end{array}$ & $=$ & ă & 2 & $\begin{array}{l}\infty \\
\ddot{n}\end{array}$ & $\stackrel{m}{+}$ & $\begin{array}{l}\infty \\
\dot{m}\end{array}$ & $\hat{n}$ & $\begin{array}{l}\infty \\
\stackrel{0}{r}\end{array}$ & 인 & $\stackrel{\nabla}{\infty}$ & $\stackrel{త}{ }$ & 8 \\
\hline
\end{tabular}

Key: $\mathrm{F}=$ frequency, $1=$ strongly Agree, 2=Agree, 3 = Undecided, 4= Disagree \& $5=$ Strongly Disagree

Table 4 presents the students' response to using meta cognitive vocabulary learning strategies. In item 15, $64.4 \%$ of the respondents responded strongly disagree, $22.5 \%$ of the respondents responded disagree and the remaining $13.3 \%$ of the respondents responded undecided to the statement. This shows that the majority of the students $(64.4 \%)$ do not give much emphasis on vocabulary items than grammar items when they learn a foreign language. If many of them give less attention to the vocabulary learning, they cannot construct grammatically correct sentences. The finding confirms Wilkins' (1976) report. Wilkins (1976) has reported that without grammar, very little can be conveyed, but without vocabulary, nothing can be conveyed. Similarly, this finding firms Harmer's (1991) report. Harmer (1991) has reported that if language structures make up the skeleton of language, then it is vocabulary that provides the vital organs and the flesh. Therefore, an ability to manipulate grammatical structure does not have any potential for expressing meaning unless words are used.

For item $16,41.7 \%, 25.8 \%, 16.7 \%$ and $15.8 \%$ of the students responded undecided, disagree, strongly agree and strongly disagree to the statement. It indicates that the majority of the respondents $(41.7 \%)$ do not practice the newly learned words by constructing sentences.

Regarding to the frequency of knowing new words in a given situation which the words are used in a context appropriately for learning new words $62.5 \%, 25.8 \%$ and $11.7 \%$ of the students responded strongly disagree, disagree and undecided respectively. This means the majority of the respondents $(62.5 \%)$ do not know new words in a given situation which the words are used in a context appropriately for learning new words

For item $18,35.8 \%$ of the students responded undecided, $30.8 \%$ of the students responded disagree, $15.8 \%$ of the students responded agree, $9.2 \%$ of the students responded strongly agree, and the remaining $8.4 \%$ of the students responded strongly disagree with the statement: they use important words inside and outside the classroom setting. This shows the majority of the respondents $(35.8 \%)$ do not decide to use important words inside and outside the classroom setting for learning new words.

Research question: How are you aware of the importance of vocabulary learning strategies for learning new words? Seventy students are aware of the importance of two vocabulary learning strategies such as the dictionary and the guessing strategies. Furthermore, thirty-one students have awareness for the importance of the vocabulary learning strategies such as the strategies of antonyms and synonyms. In addition, twenty- nine students are aware of the importance of vocabulary learning strategies which are the encoding and the repetition vocabulary learning strategies (memory strategies). Most students are aware of the importance of very limited memory, cognitive, social and metacognitive strategies so that these students would have insufficient awareness for importance of vocabulary learning strategies which help students to learn the meanings of unknown words. It means that students were not aware if vocabulary learning strategies are important because the acquisition of vocabulary is a never-ending process and can solve lots of difficulties for language learners. Therefore, to develop the students' awareness on vocabulary learning strategies and to solve lots of difficulties for language learners, it is crucial to be aware of the vocabulary learning strategies and how students adopt the strategies effectively. That is to say, it is vital to gain more insights into how learners perceive the use of vocabulary learning strategies to help them learn vocabulary.

Regarding the question: How do you practice vocabulary learning strategies in your vocabulary learning? Forty-seven students replied that they use a limited number of vocabulary learning strategies such as antonyms and synonyms in their vocabulary learning very carefully. Moreover, sixty-one students replied that they actually use an electronic dictionary strategy from their mobiles to learn the meanings of unknown words. Similarly, twelve students replied that they learn new words by asking for help to know the meanings of unknown words. From these responses, it is possible to say that all students do not try to practice a lot using different types of 
vocabulary learning strategies effectively when the situation requires to.

\subsection{Analyses of Students' Interview}

All of the interviews emphasized on vocabulary learning strategies. The interviews consisted of six items which were administered to the six students. The six students interviewed for the main study are coded as PS1-PS6 (Preparatory Student 1 to Preparatory Student 6). Therefore, the researcher began to show the six responses of interviewees for each item in the following way:

Regarding the question: Do you use sufficient vocabulary when you communicate with someone or others effectively?

Four students (PS1, PS3, PS5 and PS6) responded 'No, I don't'" to the interview. However, the remaining two students (PS2 and PS4) responded 'YYes, I do' 'to the interview. The majority of the interviewees indicate negative performance. However, Krashen (1998) that she has stated vocabulary is basic to communication. If acquirers do not recognize the meanings of the key words used by those who address them, they will be unable to participate in the conversation. And if they wish to express some ideas or ask for information, they must be able to produce lexical items to convey their meaning.

Regarding the question if students use contextual clues to guess the meanings of new words in EFL classes, five of the interviewees (PS1, PS2, PS4, PS5 and PS6) give negative replies to the interview. However, one interviewee (PS3) gives positive answer to the interview. It means that most of the students (PS1, PS2, PS4, PS5 and PS6) do not use contextual clues to guess the meanings of new words in the target language. To the contrary of this Lawson and Hogben (1996) have stated that the use of contextual clues would serve as a means toward vocabulary acquisition, but this strategy was used rarely and, even when used, was not found effective. They admitted that when the contextual clues helped students to generate the meaning, they might not pay much attention to the word and, therefore, have less chance to acquire it.

Regarding the question if they comprehend the reading text which contains some unknown words, five of the interviewees (PS1, PS3, PS4, PS5 and PS6) give negative replies to the interview. However, the remaining one interviewee (PS2) gives a positive response to the interview. From these responses, one can understand that the majority of the students do not comprehend the reading text which contains some unknown words.

Regarding to how they aware of the importance of your vocabulary learning strategies for learning new words, two students (PS1 and PSP4) are aware of the importance two vocabulary learning strategies such as the dictionary and the guessing strategies. The other three students (PS2, PS3 and PS6) have awareness for the importance of the vocabulary learning strategies such as the strategies of antonyms and synonyms. The last student (PS5) is aware of the importance of vocabulary learning strategies which are the encoding and the repetition vocabulary learning strategies (memory strategies). These students (PS1, PS2, PS3, PS4, PS5 and PS6) do not have any awareness for using useful learning strategies according to the situation that requires to. From these responses, it is possible to say that most of the students are aware of the importance of very limited memory, cognitive, social and metacognitive strategies so that the students will have problems to be aware of the importance of vocabulary learning strategies which help them to learn the meanings of unknown words. The finding confirms Asgari and Mustapha's (2011) report. Asgari and Mustapha (2011) have indicated that vocabulary has been recognized as crucial to language use in which insufficient vocabulary knowledge of the learners led to difficulties in second language learning. Therefore, the word strategy indicates some degree of awareness on the part of the learner. If foreign language learners are equipped with strategies such as vocabulary learning strategies, they can be much more successful language learners because vocabulary learning strategies make students autonomous and enable them to take responsibility of their own learning (Oxford, 1990).

Regarding the question how they practice vocabulary learning strategies in their vocabulary learning, two students (PS1 and PS4) replied that they use a limited number of vocabulary learning strategies such as antonyms and synonyms in their vocabulary. For example, PS1 says, "I carefully practice only a few vocabulary learning strategies such as antonyms and synonyms for learning new words." The other three students (PS2, PS3 and PS5) replied that they actually use an electronic dictionary strategy from their mobiles to learn the meanings of unknown words. The last student (PS6) replies that he learns new words by asking for help to know the meanings of unknown words. From these responses, it is possible to say that all the interviewees (PS1, PS2, PS3, PS4, PS5 and PS6) do not practice using different types vocabulary learning strategies effectively when the situation requires to. The students indicate negative performance. It implies that there is a negative atmosphere in the teaching and learning process. For example, the process of reading skill can be affected the lack of the knowledge of students' vocabulary learning strategies.

\subsection{Analyses of Teachers' Interview}

All of the interviews emphasized on vocabulary learning strategies. The interviews consisted of five items which were administered to the two EFL teachers. The two EFL teachers interviewed for the main study were coded as PT1 and PT2 (Preparatory Teacher 1 and Preparatory Teacher 2). 
Regarding the question if they initiate their students to use sufficient vocabulary when they communicate with someone or others effectively, the EFL teachers (PT 1 and PT 2) gave almost similar answers to the question. They said that the students have low interest to communicate between and among them due to lack of vocabulary knowledge. For example, PT1 says, 'No, I don't. My students have low interest to use the target language in communication because they have insufficient vocabulary knowledge."

For the question "Do you encourage your students to use contextual clues to guess the meanings of new words in EFL classes?" They say that their performance is negative because of the students' insufficient vocabulary knowledge. For example, PT1 says, 'No, I don't. My students have insufficient vocabulary knowledge." Although as Lawson and Hogben's (1996) indicated the context helped students to generate the meaning, the teachers didn't encourage students to use contextual clues to guess new words. The use of contextual clues would serve as a means toward vocabulary acquisition, but this strategy was used rarely and, even when used, was not found effective.

Regarding the question: Do you motivate your students to comprehend the reading text which contains some unknown words? The two EFL teachers gave similar answer to the question which is negative because their students do not use the vocabulary learning strategies to comprehend the reading text by consolidating the meanings of unknown words from it. For example, PT2 says, 'No, I don't. My students do not use vocabulary learning strategies for learning new words."

Regarding the question: How are your students aware of the importance of their vocabulary learning strategies for learning new words? PT1 responded, "By making students use the vocabulary learning strategies such as the guessing, repetition, note - taking, memory and association strategies are important vocabulary leaning strategies to develop their vocabulary knowledge, but most of the time, I do not employ them in EFL classes because the students do not actively participate in applying the strategies. In addition, it takes much time to make students practice the strategies." While PT2 said that, "Students can develop their awareness and their vocabulary knowledge by using the memory, cognitive and social strategies, but I rarely use the strategies in EFL classes." From the response it is possible to say that despite knowing vocabulary learning strategies, teachers do not make students practice the strategies. Therefore, it is possible to say that the students do not practice the strategies.

It can be said that through the use of vocabulary learning strategies, learners may be able to maximize the effectiveness of their English language learning. On this basis, it is crucial to be aware of the basics of vocabulary learning strategies and how students adopt the strategies effectively. That is to say, it is vital to gain more insights into how students perceive the use of vocabulary learning strategies to help them learn vocabulary. In relation to this Oxford (1990), states that language learning strategies play a very vital role in foreign language learning. They may be applied to simple tasks such as learning a list of new words, or more complex tasks involving language comprehension and production (Richards, 1976). If foreign language learners are equipped with strategies such as vocabulary learning strategies, they can be much more successful language learners because vocabulary learning strategies make students autonomous and enable them to take responsibility of their own learning (Oxford, 1990).

\subsection{Analyses of Observations}

As presented in the research methodology section, observations of two sections of grade 11 were conducted prior to the distribution of the questionnaire. The result of the observations as shown in table 5 (classroom observation checklist) was analyzed and discussed in the following way 
Table 7. Classroom Observation Checklist

\begin{tabular}{|c|c|c|c|c|c|c|c|c|c|}
\hline \multirow[b]{2}{*}{ 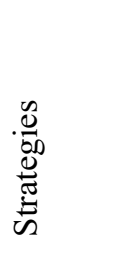 } & & \multirow{2}{*}{ Statements } & \multicolumn{3}{|c|}{ Alternatives } & \multicolumn{2}{|c|}{ PT 1} & \multicolumn{2}{|c|}{ PT 2} \\
\hline & & & $\stackrel{x}{11}$ & $\begin{array}{l}\vec{E} \\
\stackrel{D}{D} \\
\|\end{array}$ & $\underset{5}{5}$ & $\begin{array}{l}\mathrm{D} \\
1\end{array}$ & $\begin{array}{l}\mathrm{D} \\
2\end{array}$ & D1 & \\
\hline \multirow{6}{*}{ 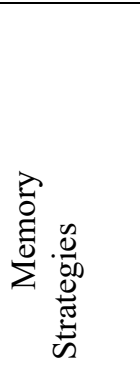 } & & \multirow{3}{*}{$\begin{array}{l}\text { The students are encouraged to learn the meanings of } \\
\text { new words by the help of repetition. } \\
\text { - Rehearsal } \\
\text { - } \quad \text { Word list }\end{array}$} & \multicolumn{3}{|c|}{1} & $\sqrt{ }$ & $\sqrt{ }$ & $\sqrt{ }$ & $\sqrt{ }$ \\
\hline & & & \multicolumn{3}{|c|}{2} & & & & \\
\hline & & & \multicolumn{3}{|c|}{3} & & & & \\
\hline & & \multirow{3}{*}{$\begin{array}{l}\text { The students are initiated to learn the meanings of } \\
\text { new words by the help encoding. } \\
\text {-word association } \\
\text {-pictures, real objects, }\end{array}$} & \multicolumn{3}{|c|}{1} & $\sqrt{ }$ & $\sqrt{ }$ & $\sqrt{ }$ & $\sqrt{ }$ \\
\hline & & & \multicolumn{3}{|c|}{2} & & & & \\
\hline & & & \multicolumn{3}{|c|}{3} & & & & \\
\hline \multirow{6}{*}{\multicolumn{2}{|c|}{ 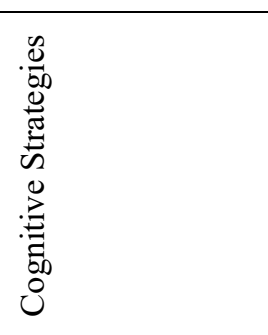 }} & \multirow{3}{*}{$\begin{array}{l}\text { The students are encouraged to discuss their feelings } \\
\text { with someone for learning new words. }\end{array}$} & \multicolumn{3}{|c|}{1} & $\sqrt{ }$ & $\sqrt{ }$ & $\sqrt{ }$ & $\sqrt{ }$ \\
\hline & & & \multirow{2}{*}{\multicolumn{3}{|c|}{$\frac{2}{3}$}} & & & & \\
\hline & & & & & & & & & \\
\hline & & \multirow{3}{*}{$\begin{array}{l}\text { The students are motivated to guess the meanings of } \\
\text { new words in a text by activating background } \\
\text { knowledge using linguistic items. } \\
\begin{array}{cl}\text { - } & \text { Use of dictionary } \\
- & \text { Use of note - taking }\end{array}\end{array}$} & \multicolumn{3}{|c|}{1} & $\sqrt{ }$ & $\sqrt{ }$ & $\sqrt{ }$ & $\sqrt{ }$ \\
\hline & & & \multicolumn{3}{|c|}{$\frac{2}{3}$} & & & & \\
\hline & & & \multicolumn{3}{|c|}{3} & & & & \\
\hline \multirow{6}{*}{ 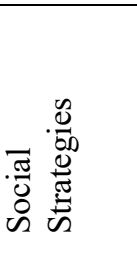 } & \multirow{6}{*}{ 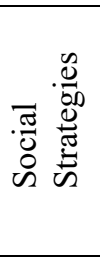 } & \multirow{3}{*}{$\begin{array}{l}\text { The students are encouraged to practice the newly } \\
\text { learned words by speaking to a friend and so on. }\end{array}$} & \multirow{2}{*}{\multicolumn{3}{|c|}{$\frac{1}{2}$}} & $\sqrt{ }$ & $\sqrt{ }$ & $\sqrt{ }$ & $\sqrt{ }$ \\
\hline & & & & & & & & & \\
\hline & & & \multicolumn{3}{|c|}{3} & & & & \\
\hline & & \multirow{3}{*}{$\begin{array}{l}\text { The students are motivated to cooperate with others } \\
\text { for learning new words. }\end{array}$} & \multicolumn{3}{|c|}{1} & $\sqrt{ }$ & $\sqrt{ }$ & $\sqrt{ }$ & $\sqrt{ }$ \\
\hline & & & \multirow{2}{*}{\multicolumn{3}{|c|}{$\frac{2}{3}$}} & & & & \\
\hline & & & & & & & & & \\
\hline \multirow{5}{*}{\multicolumn{2}{|c|}{ 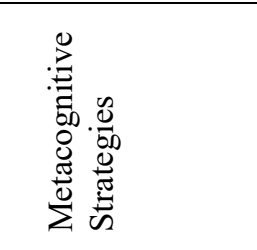 }} & \multirow{3}{*}{$\begin{array}{l}\text { The students are encouraged to pay attention to their } \\
\text { vocabulary learning by using the suitable vocabulary } \\
\text { learning strategies. }\end{array}$} & 1 & & & $\sqrt{ }$ & $\sqrt{ }$ & $\sqrt{ }$ & $\sqrt{ }$ \\
\hline & & & 2 & & & & & & \\
\hline & & & 3 & & & & & & \\
\hline & & The students are motivated to have self - monitoring & 1 & & & $\sqrt{ }$ & $\sqrt{ }$ & $\sqrt{ }$ & $\sqrt{ }$ \\
\hline & & and self - evaluating process for learning new words. & $\frac{2}{3}$ & & & & & & \\
\hline
\end{tabular}

Adapted from Getnet's (2008) classroom observation checklist.

Key: Ex = excellent, Sat $=$ Satisfactory, $U n=$ Unsatisfactory, $P T 1=$ Preparatory teacher $1, P t 2=$ Preparatory teacher 2, D1= Day 1, D2= Day 2 .

As it was shown in the above table, the four types of vocabulary learning strategies were observed and recorded using the classroom observation checklist. The results of the observation in each vocabulary learning strategy were summarized in themes as follows.

\section{A. Memory Strategy}

As it is shown in table 5, this is the strategy which teachers did not play their major roles and didn't help the students. In the observed two sections, the teachers did not explain and help the students to learn the new words. These two teachers did not make the students active in guessing the meanings of new words. From these observations, it is possible to say that the students are not encouraged to learn the meanings of new words by the help of repetition and encoding strategies. It means the memory strategy is a significant strategy, but the two teachers do not encourage their students to use it when the students learn new words in EFL classes. In these two sections, the majority of the students were not made to genuinely interact and they did not show interest in the whole activity, but only a few students were observed interacting in English and interested in the teaching and learning process. This situation makes the students have low performance in vocabulary.

\section{B. Cognitive Strategy}

Like memory strategies, the cognitive strategies were not used by the students who were expected to do the activities such as discussing their feelings with someone and guessing the meanings of new words for learning new words in the classroom. It means that the students in the two sections were no encouraged to discuss their feelings with someone for learning new words. Moreover, those students were not motivated to guess the 
meanings of new words by activating background knowledge using linguistic items.

\section{Social Strategy}

From Table 5, one could understand that the students in the two sections were not encouraged to practice the newly learned words by speaking to someone and the like. They were not also motivated to cooperate with others for learning new words. From this observation, it is possible to say that most students would not employ the new words that they have learned in their speech and writing. The finding showed that those learners have not confidence and put in effort in practicing the newly leaned words and cooperating with others for learning new words.

As words get more difficult, students begin to find fewer and fewer meanings. Thus, it is usually their most common words that they get into the most trouble. Moreover, problems in vocabulary learning strategies can make the language skills non-functional. If there is a problem of vocabulary, it is impossible to carry out the four main language skills. If students do not recognize the meanings of the key words, they will be unable to participate in the conversation. And if they wish to express some ideas or ask for information, they must be able to produce lexical items to convey their meanings.

\section{Metacognitive Strategies}

As the researcher observed in the two sections, most of the students were not made to become active in the teaching and learning process. They were not also motivated to pay attention to the students' vocabulary learning by using the suitable vocabulary learning strategies, and they were not encouraged to employ self - monitoring and self - evaluating activities for learning new words. Using the metacognitive strategies, students were not initiated to find out the meaning of unknown words, to retain them in long-term memory, to recall them and to use them in oral or written mode. Students encounter problems or difficulties in using metacognitive strategies for learning new words. The finding confirms that ideas do not travel best in words. Students do not share their ideas and feelings directly or indirectly through words. If they are not going to be an effective communicator, they cannot distinguish word meanings and apply that understanding to their vocabulary learning. To communicate their ideas to friends and so on, either in speaking or in writing, they cannot choose their words with care. Thus, problems in vocabulary learning strategies can make the language skills non-functional.

\section{Conclusion and Recommendation}

\subsection{Conclusion}

Based on the analysis of the data, the following conclusions were obtained from the study:

1. Most of the students were not aware of the important vocabulary learning strategies which are used for learning the meanings of new words in the target language. There were various important vocabulary learning strategies such as memory strategies - are classified into two distinct categories; rehearsal and encoding categories; cognitive strategies-- consist of guessing strategies, skillful use of dictionaries and note-taking strategies; social/affective/activation strategies -- include those strategies through which the learners actually use new words in different contexts and metacognitive strategies - consist of strategies for selective attention and self-initiation.

2. Most of the students did not practice the various vocabulary learning strategies such as memory strategies, cognitive strategies, social strategies and metacognitive strategies for learning new words in the target language.

\subsection{Recommendation}

From the findings found and the conclusions drawn, the following recommendations were made:

1. Teachers shout create aware for students about the importance of the different types of vocabulary learning strategies with their functions for learning new words.

2. Most of the students should practice the different types of vocabulary learning strategies very carefully for learning new words.

\section{Reference}

Abebe gebre- Tsadik .1997. Strategies of Vocabulary Learning employed by first year students of AAU of Freshman English as a Second/Foreign Language. Unpublished PhD. Thesis Submitted to school of Graduate. Addis Ababa: Addis Ababa University.

Ahmed, M.O .1998. Vocabulary Learning Strategies: In Beyond Words.3-14. Paul Meara (ed). London: CILT. Anderson, N. 1999. Exploring Second Language Reading. Canada: Heinle \& Heinle Publishers.

Ary, D., Jacobs, L.C., Sorensen, C. and Razavieh, A. 2010. Introduction to Research in Education. Wadsworth Cengage learning, USA

Asgari, A., \& Mustapha, G. B. 2011. The Type of Vocabulary Learning Strategies Used by ESL Students in University Putra Malaysia. English Language Teaching, 4(2), p84.

Cameron, L. 2001. Teaching language to Yong Learners. UK: Cambridge University Press. 
Creswell, J. W. 2014. Qualitative, Quantitative and Mixed Method Approaches. SAGE Publications Ltd. California, USA

Dickinson,L. 1987. Self-Instruction in Language Learning. Cambridge: Cambridge University Press.

Getnet Gidey. 2008. Vocabulary-Learning Strategy Use: The Case of High and Low Achiever Students in Gondar College of Teacher Education. Unpublished MA Thesis. Gonder: Gondar College of Teacher Education.

Harmer, J. 1991. The Practice of English Language Teaching. New York: Longman.

Hatch,E and Brown, C. 1995. Vocabulary, Semantics and Language Education. Cambridge: Cambridge University Press.

Krashen, K. 1998. TPR: Still a Very Good Idea. System.5:4, 82-85.

Kumar, S.Y. 2006. Fundamental of Research Methodology \& Statistics. New Delhi: New Age International (P) Ltd.

Lawson, M. and Hogben, D. 1996. The Vocabulary Learning Strategies of Foreign- Language Students. TESL Journal, 46:1:101-135.

McCarthy, M. 1990. Vocabulary. Oxford: Oxford University Press.

Nation,P. 1990. Teaching and Learning Vocabulary. New York: Newbury House.

O' Malle, M.J. and Chamot, N.A. 1990. Learning Strategies in School Language Acquisition. Cambridge: Cambridge University Press.

Oxford, R. 1990. Language Learning Strategies: What Every Teacher Should Know. New York: Newbury House.

Richards, J.C. 1976. The Role of Vocabulary Teaching. TESOL Quarterly, 10(1),77.

Schmitt,N. 1997. Vocabulary Learning Strategies. In Vocabulary: Description, Acquisition and Pedagogy N. Schmitt and M. McCarthy (Eds). (pp.199-228). Cambridge: Cambridge University Press.

Wallace, M.J. 1982. Teaching vocabulary. London: Heinemann Education Books Ltd.

Wilkins, D.A. 1976. Second Language Learning and Teaching. London: Eduward Arneid Ltd. 1982. Linguistics in Language Teaching. London: Educational Arnold Publishing Ltd. 